\title{
Epithelioid Leiomyosarcoma
}

National Cancer Institute

\section{Source}

National Cancer Institute. Epithelioid Leiomyosarcoma. NCI Thesaurus. Code C3700.

A morphologic variant of leiomyosarcoma characterized by the presence of epithelioid round cells with eosinophilic to clear cytoplasm. 